\title{
Capital Structure Theory: An Overview
}

\author{
D.K.Y Abeywardhana ${ }^{1}$ \\ ${ }^{1}$ Department of Accountancy, University of Kelaniya, Sri Lanka \\ Correspondence: D.K.Y Abeywardhana, Department of Accountancy, University of Kelaniya, Sri Lanka
}

Received: December 14, 2016

Accepted: January 27, 2017

Online Published: January 28, 2017

doi:10.5430/afr.v6n1p133

URL: http://dx.doi.org/10.5430/afr.v6n1p133

\begin{abstract}
Capital structure is still a puzzle among finance scholars. Purpose of this study is to review various capital structure theories that have been proposed in the finance literature to provide clarification for the firms' capital structure decision. Starting from the capital structure irrelevance theory of Modigliani and Miller (1958) this review examine the several theories that have been put forward to explain the capital structure.

Three major theories emerged over the years following the assumption of the perfect capital market of capital structure irrelevance model. Trade off theory assumes that firms have one optimal debt ratio and firm trade off the benefit and cost of debt and equity financing. Pecking order theory (Myers, 1984, Myers and Majluf, 1984) assumes that firms follow a financing hierarchy whereby minimize the problem of information asymmetry. But neither of these two theories provide a complete description why some firms prefer debt and others prefer equity finance under different circumstances.

Another theory of capital structure has introduced recently by, Baker and Wurgler (2002), market timing theory, which explains the current capital structure as the cumulative outcome of past attempts to time the equity market. Market timing issuing behaviour has been well established empirically by others already, but Baker and Wurgler (2002) show that the influence of market timing on capital structure is regular and continuous. So the predictions of these theories sometimes acted in a contradictory manner and Myers (1984) 32 years old question "How do firms choose their capital structure?" still remains.
\end{abstract}

Keywords: Capital structure, Pecking order theory, Trade off theory, Market Timing Theory

\section{Introduction}

The second financing choice faced by the firm, Capital Structure is still a puzzle in finance. Capital structure or financial leverage decision should be examined concerning how debt and equity mix in the firm's capital structure influence its market value. Debt to equity mix of the firm can have important implications for the value of the firm and cost of capital. In maximizing shareholders wealth firm use more debt capital in the capital structure as the interest paid is a tax deductible and lowers the debt's effective cost. Further equity holders do not have to share their profit with debt holders as the debt holders get a fixed return. However, the higher the debt capital, riskier the firm, hence the higher its cost of capital. Therefore it is important to identify the important elements of capital structure, precise measure of these elements and the best capital structure for a particular firm at a particular time.

Researchers and practitioners explain conflicting theories on capital structure. Durand (1952) states using the Net Income (NI) approach that firm can decrease its cost capital and consequently increase the value of the firm through debt financing. In contrast, Modigliani and Miller (1958) claims in their seminal paper capital structure irrelevance that firm's value is independent of its debt to equity ratio which is known as Net Operating Income (NOI) approach. They argue that perfect capital market without taxes and transaction cost the firm value remain constant to the changes in the capital structure. According to Pandey (2007) the traditional approach of Solaman,(1963) has emerged a compromise to the extreme position taken by the NI approach. Traditional approach does not assume constant cost of equity change in debt to equity ratio and continuously declining Weighted Average Cost of Capital (WACC). Further this approach assume the concept of optimal capital structure and thereby very clearly implies that WACC decreases only for a certain level of financial leverage and reaching the minimum level. Further increase in financial leverage would increase the WACC. 
During the past five decades various theories have been developed and to explain the capital structure and value of the firm and main factors determining capital structure. Simultaneously enormous number of empirical studies have also tried to explain these theories and their effectiveness.

\section{Capital Structure Theories}

\subsection{Capital Structure Irrelevance Theory of Modigliani and Miller}

Capital structure irrelevance theory of Modigliani and Miller (1958) is considered as the starting point of modern theory of capital structure. Based on assumptions related to the behavior of investors and capital market MM illustrates that firm value is unaffected by the capital structure of the firm. Securities are traded in perfect capital market, all relevant information are available for insiders and outsiders to take the decision (no asymmetry of information), that is transaction cost, bankruptcy cost and taxation do not exist. Borrowing and lending is possible for firms and individual investors at the same interest rate which permits for homemade leverage, firms operating in a similar risk classes and have similar operating leverage, interest payable on debt do not save any taxes and firms follow $100 \%$ dividend payout. Under these assumptions MM theory proved that there is no optimal debt to equity ratio and capital structure is irrelevant for the shareholders wealth. This preposition presented by MM (1958) in their seminal paper and argue that value of levered firm is same as the value of unlevered firm. Therefore they propose that managers should not concern the capital structure and they can freely select the composition of debt to equity. Important contributions to the MM approach include Hirshleifer (1966) and Stiglitz (1969). Further in their preposition II they claim that increase in leverage increase the risk of the firm and as a result the cost of equity increases. But WACC of the firm remain constant as cost of debt compensate with higher cost of equity.

Capital structure irrelevance theory was theoretically very sound but was based on unrealistic set of assumptions. Therefore this theory led to a plenty of research on capital structure. Even though their theory was valid theoretically, world without taxes were not valid in reality. In order to make it more accurate Modigliani and Miller (1963) incorporated the effect of tax on cost of capital and firm value. In the presence of corporate taxes, the firm value increase with the leverage due to the tax shield. Interest on debt capital is an acceptable deduction from the firm's income and thus decreases the net tax payment of the firm. This would result in an added benefit of using debt capital through lowering the capital cost of the firm. Drawbacks in MM theory stimulated series of research devoted on proving irrelevance as theoretical and empirical matter.

So may other theories that contribute to capital structure theorem have developed based on the MM theorem and it is much hard to validate any of them. Even though there are weaknesses in MM theorem it cannot be completely ignored or excluded.

\subsection{Trade off Theory}

One of the basic theory that have dominated the capital structure theory which recommends that optimal level of the debt is where the marginal benefit of debt finance is equal to its marginal cost. Firm can achieve an optimal capital structure through adjusting the debt and equity level thereby balancing the tax shield and financial distress cost. There is no consensus among researchers on what consist the benefit and costs. Eliminating the constraints of the capital structure irrelevance proposition of MM Myers (1984) use the trade of theory as a theoretical foundation to explain the "Capital Structure Puzzle". Myers (1977) suggest that the use of debt up to a certain level offset the cost of financial distress and interest tax shield. According to Fama and French (2002) the optimal capital structure can be identified through the benefits of debt tax deductibility of interest and cost of bankruptcy and agency cost. 


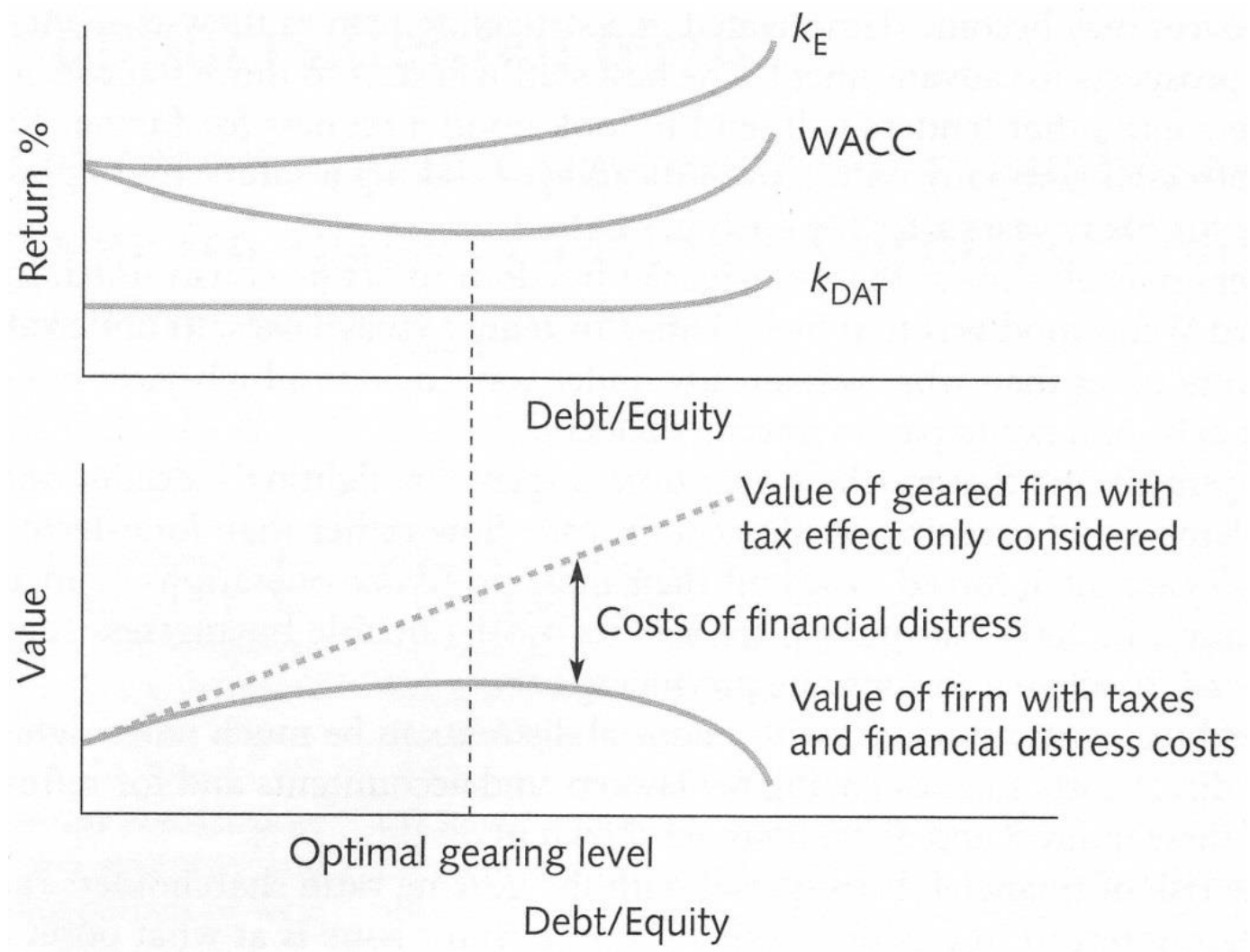

\section{Source: Arnold (2008)}

Figure 1.

Arnold (2008) explains how is the increase in debt capital in the capital structure effect the value of the firm in the Figure 1. As debt capital increase WACC of the firm declines until the firm reaches the optimal gearing level and cost of financial distress increases along with the debt level. This is confirmed by Miller (1988) that the optimal debt to equity ratio shows the highest possible tax shield that the company can enjoy. Further consistent with Modigliani and Miller (1963), Miller (1988) confirmed the fact that firms increase the risk of bankruptcy due to the debt capital in their capital structure. In the trade off theory cost of debt are linked with direct as well as indirect cost of bankruptcy. Bradley et. al., (1984) explained that cost of bankruptcy include legal and administrative cost, other indirect cost resulting from loosing of customers and trust between staff and suppliers due to the uncertainties.

Apart from the bankruptcy cost, agency cost of Jenson and Meckling (1976) is also considered in the trade off model. Jenson and Meckling (1976) explains that separation of ownership and control is the reason to rise the agency cost. According to Arnold (2008) agency costs are direct and indirect costs result from principles and agents act in their best interest and, failure to make agents to act this way.

Jenson (1986) states that debt can reduce the agency cost and argue that higher the debt capital grater the commitment to pay out more cash. Though, Frank and Goyal (2008) contend that it is not been totally explained the impact of agency conflicts on capital structure. Harris and Raviv (1990) suggest that debt capital in the capital structure produce valuable information in monitoring the agency behavior and for self-interest reasons managers are reluctant to liquidate the firm or provide such information which could lead to bankruptcy. Debt holders also concerned only on their benefit and would prefer firms to undertake safe investments nut do not bother about the profitability of those investments. This further explains Fama and French (2002) that due to the cost of debt agency conflicts arise between shareholders and bondholders.

Brounen et. al., (2005) states that the presence of optimal capital structure or target capital structure increase the shareholder wealth. Further this study explains that even the value maximizing firm use debt capital to full capacity they face low probability of going bankrupt. Hovakimian et. al. (2004) claims that high profitability of gearing proposes that the firms' tax shield higher and lower the possibility of bankruptcy. This is consistent with the key prediction of the trade-off model that there is a positive correlation between profitability and gearing. But none of 
these theoretical and empirical studies fully substitute the traditional version and therefore researchers still test the trade-off theory based on the original assumptions. In the literature contradictory evidence can be found in favor and against the trade-off model and optimal capital structure. Titman and Wessels (1988) found that non-debt tax shield and use of debt capital in the capital structure is positively correlated. Contradictory to this results. Consistent with Modigliani and Miller (1963) Mackie-Mason (1990) found that firms which incur a tax loss are rarely issue debt capital. Gearing level of the firms are steady even the tax rates vary to great extent (Wright, 2004). Contrary to this Graham and Harvey (2001) revealed that capital structure choice depend on tax rates.

Optimal capital structure choice of the firm would be to issue debt capital and/or equity capital. Trade off theory postulate that all firms have an optimal debt ratio at which the tax shield equal the financial distress cost. This theory eliminate the impact of information asymmetry and incorporating the different information on conflicts between insiders and outsiders Pecking Order Theory proposed.

\subsection{Pecking Order Theory}

Assuming perfect capital market as proposed by MM (1958), Myers and Majluf (1984) propose pecking order theory following the findings of Donaldson (1961) which found that management prefer internally generated funds rather using external funds. Pecking order theory suggest that firm prefer internal financing over debt capital and explains that firms utilize internal funds first then issue debt and finally as the last resort issue equity capital. Al-Tally (2014) confirmed the same that firms prefer to finance new investments with internally generated funds first and then with debt capital and as the last resort they would go for equity issue. Pecking order theory further explains that firms borrow more when internally generated funds are not sufficient to fulfill the investment needs ((Shyam-Sunder and Myers, 1999). This is confirmed by Myers (2001) and found that debt ratio of the firm reflect the cumulative figure for external financing and firms with higher profit and growth opportunities would use less debt capital. If the firm has no investment opportunities profits are retained to avoid the future external financing. Further firms' debt ratio represent the accumulated external financing as the firm do not have optimal debt ratio.

Based on the pecking order theory Harris and Raviv (1991) claim that capital structure decisions are intended to eliminate the inefficiencies caused by information asymmetry. Information asymmetry between insiders and outsiders and separation of ownership explain why firms avoid capital markets (Myers, 2001). Frydenberg (2004) explains that debt issue of a firm give a signal of confidence to the market that firm is an outstanding firm that their management if not afraid of debt financing. Further Frank and Goyal (2007) show that due to the agency conflict between managers and owners and outside investors pecking order can occur.

Studies on pecking order theory have not been able to show the significance of this theory on determining firms' capital structure. Fama and French (1998) compared the trade off theory and pecking order theory and shows that certain features of financial data are better described by the pecking order theory. This is confirmed by Shyam-Sunder and Myers (1999) Raj Aggarwal et al (2006) and Karadeniz et al (2009). Shortcomings in this theory pressed the further development of the theories of capital structure to solve the capital structure puzzle.

\subsection{Market Timing Theory}

Market timing theory of capital structure explains that firms issue new equity when their share price is overrated and they buy back shares when the price of shares are underrated (Baker and Wurgler, 2002). This fluctuation in the price of shares affect the corporate financing decisions and finally the capital structure of the firm. Further Baker and Wurgler (2002) explains that consistent with the pecking order theory of capital structure market timing theory does not move to target leverage as equity transactions are completely time to stock market conditions. This implies that capital structure changes persuaded by market timing are long lasting (Bessler et al, 2008).

This preposition explains that gearing ratios are negatively related to the past stock returns (Bessler 2004) and Welch (2004) found that the most important determinant of capital structure is the stock returns. However Hovakimian (2006) stated that market timing does not have a significant effects on the firms' capital structure in the long run. Confirming the same Alti (2006) shows that impact of market timing on gearing will entirely fades within two years.

\subsection{Credit Rating - Capital Structure (CR-CS) Hypothesis}

Kisgen (2006) proposed CR-CS hypothesis as an extension of the existing trade off theory of capital structure. Capital structure decision would change based on the cost and benefit associated with the different rating levels. Further Kisgen (2006) explains that credit rating changes directly affects capital structure decision of the firm and when the firms closer to a rating change issues less debt capital than firms not closer a rating change. CR-CS hypothesis complements traditional capital structure theories in deciding the capital structure. 


\section{Conclusion}

Understanding the capital structure decision of firms is the focus of the all the theories discussed above. Modigliani and Miller (1958) theorem of capital structure irrelevance which was developed based on the fundamental nature of debt and equity of the firm and unrealistic assumptions pave the way to the other theories of capital structure. The pecking order theory explains how company raises funds following a hierarchy whereas trade off theory advocates tax shield advantage and value maximizing through the optimal debt to equity mix. Ladder of preference use in the pecking order theory and the tax shield advantage of the trade off theory leads to the same conclusion. The tax shield advantage provides rational for the preference for external debt and which signify trade off theory as complementary to the pecking order theory. Differences in capital structure theories occurs in their explanations of significance of taxes and changes in information and agency costs. These theories that have been developed based on Modigliani and Miller (1958) would work healthy under some assumptions only but they do not clarify actual gearing level adopted by firms. Further market timing theory do not explain an optimal capital structure and according to this theory capital structure is an outcome of various different decisions the firm has taken over time. This theory suggests that firms issue new shares when they notice they are overrated and that firms repurchase own shares when they consider these to be underrated. It is important to have more comprehensive view on capital structure of firms as these theories are not being able to explain everything. This proposes that there is no single theory on capital structure which incorporates all important factors and predictions of this theories suggest that capital structure puzzle still remains.

\section{References}

Aggarwal, R \& Aung Kyaw, N. (2006). Leverage, Investment Opportunities, and Firm Value: A Global Perspective on the Influence of Financial Development. FMA Annual Meeting, Salt Lake city USA.

Al-Tally, H. A. (2014). An investigation of the effect of financial leverage on firm financial performance in Saudi Arabia's public listed companies (Doctoral dissertation, Victoria University).

Alti, A. (2006). How persistent is the impact of market timing on capital structure? The Journal of Finance, 61(4), 1681-1710. https://doi.org/10.1111/j.1540-6261.2006.00886.x

Arnold, G. (2008). Corporate Financial Management. 4th ed. Harlow: Prentice-Hall.

Baker, M., \& J. Wurgler, (2002), Market timing and capital structure, Journal of Finance, 57. https://doi.org/10.1111/1540-6261.00414

Bessler D.A., \& David, E.E. (2004). Price discovery in the Texas cash cattle market, Applied Stochastic Models in Business and Industry, 20(4). https://doi.org/10.1002/asmb.546

Bessler, W., Drobetz, W., \& Pensa, P. (2008). Do managers adjust the capital structure to market value changes? Evidence from Europe. Zeitschrift für Betriebswirtschaft, 78(6),pp.113-145.

Bradley, M., Gregg, J.A. \& Kim, E.H. (1984). On the Existence of an Optimal Capital Structure: Theory and Evidence. The Journal of Finance. 39(3), 1421-1460. https://doi.org/10.1111/j.1540-6261.1984.tb03680.x

Brounen, D., De-Jong, A., Koedijk, K. (2005). Capital structure policies in Europe: Survey evidence. Journal of Banking \& Finance. 30(5), 1409-1442. https://doi.org/10.1016/j.jbankfin.2005.02.010

Donaldson, G. (1961). Corporate Debt Capacity: A Study of Corporate Debt Policy and the Determination of Corporate Debt Capacity. Boston: Harvard.

Durand, David. (1952). Cost of Debt and Equity Funds for Business: Trends and Problems of Measurement. In Conference on Research in Business Finance, New York: National Bureau of Economic Research, pp. 215-147.

Fama, E., \& K.R. French. (2002). Testing trade-off and pecking order predictions about dividends and debt. Review of Financial Studies, 15, 1-33. https://doi.org/10.1093/rfs/15.1.1

Frank, M.Z, \& Goyal, V.K. (2007). Tradeoff and pecking order theories of debt. In: Eckbo, B.(Ed.). Handbook of Corporate Finance: Empirical Corporate Finance. Amsterdam: North-Holland, pp.135-202.

Frydenberg, S. (2004). Determinants of Corporate Capital Structure of Norwegian Manufacturing Firms, Trondheim Business School Working Paper No. 1999:6. https://doi.org/10.2139/ssrn.556634

Graham, J.R., \& C. Harvey. (2001). The theory and practice of corporate finance: evidence from the field. Journal of Financial Economics, 60, 187-243. https://doi.org/10.1016/S0304-405X(01)00044-7 
Harris, M., \& Raviv A. (1991). The theory of capital structure. Journal of Finance, 46, 297-356. https://doi.org/10.1111/j.1540-6261.1991.tb03753.x

Hirshleifer, J. (1966). Investment Decisions under Uncertainty: Applications of the State-preference Approach. Quarterly Journal of Economics, 237-277, 1966. https://doi.org/10.2307/1880692

Hovakimian A. (2006). Are Observed Capital Structures Determined by Equity Market Timing?, The Journal of Financial and Quantitative Analysis, 41(1), (Mar., 2006), 221-243. https://doi.org/10.1017/S0022109000002489

Hovakimian, A., Hovakimian, G. \& Tehranian, H. (2004). Determinants of Target Capital Structure: the Case of Dual Debt and Equity Issues. Journal of Financial Economics, 71(3), 517-540. https://doi.org/10.1016/S0304-405X(03)00181-8

Jensen, M.C. \& Meckling, W. H. (1976). Theory of the firm: Managerial behavior, agency costs and ownership structure. Journal of Financial Economics, 3(4), 305-360. https://doi.org/10.1016/0304-405X(76)90026-X

Karadeniz, E., Kandir, Y.S., Balcilar, M. \& Onal, B.Y. (2009). Determinants of capital structure: evidence from Turkish lodging companies. International Journal of Contemporary Hospitality Management, 21(5), 594-609. https://doi.org/10.1108/09596110910967827

Kisgen, D. J. (2006). Credit Ratings and capital Structure, Journal of Finance, 61(3), pp.1035-1072. https://doi.org/10.1111/j.1540-6261.2006.00866.x

MacKie-Mason, J.K. (1990). Do Taxes Affect Corporate Financing Decisions? The Journal of Finance, 45(5), pp.1471-1493. https://doi.org/10.1111/j.1540-6261.1990.tb03724.x

Miller, M.H. (1988). The Modigliani-Miller Propositions After Thirty Years. Journal of Economic Perspectives, 2(4), 99-120. https://doi.org/10.1257/jep.2.4.99

Modigliani, F. \& Miller, M. (1958). The cost of capital, corporation finance, and the theory of investment. American economic Review, 48, June, 261-197.

Modigliani, F. \& Miller, M. (1963). Corporate income taxes and the cost of capital: A correction. American economic Review, June, 433-443.

Myers, S. C. \& Majluf, N. S. (1984). Corporate financing and investment decisions when firms have information those investors do not have. Journal of Financial Economics, 13, 187-221. https://doi.org/10.1016/0304-405X(84)90023-0

Myers, S. C. (1984). The capital structure puzzle. The journal of finance, 39(3), 574-592. https://doi.org/10.1111/j.1540-6261.1984.tb03646.x

Myers, S.C. (2001). Capital Structure. The Journal of Economic Perspectives. 15(2), 81-102. https://doi.org/10.1257/jep.15.2.81

Pandey, I. M. (2007). Financial management. (09 ed., pp. 1-10). New Delhi: VIKAS Publishing House.

Shyam-Sunder, L. \& Myers, S.C. (1999). Testing Static Tradeoff Against Pecking-Order Models of Capital Structure. Journal of Financial Economics, 51(2), 219-244. https://doi.org/10.1016/S0304-405X(98)00051-8

Solaman, Ezra. (1963). The Theory of Financial Management, University press, 1963. 92

Stiglitz, Joseph E. (1969). A Re-examination of the Modigliani-miller theorem. The American Economic Review, 59, 784-793.

Titman, S. \& Wessels, R. (1988). The Determinants of Capital Structure Choice. The Journal of Finance, 43(1), 1-19. https://doi.org/10.1111/j.1540-6261.1988.tb02585.x

Welch, I. (2004). Capital structure and stock returns. Journal of Political Economy, 112(1), 106-132. https://doi.org/10.1086/379933

Wright, S. (2004). Measures of Stock Market Value and Returns for the U.S. Nonfinancial Corporate Sector, 1900-2002. Review of Income and Wealth, 50(4), 561-584. https://doi.org/10.1111/j.0034-6586.2004.00140.x 